\title{
Título da página eletrónica: Sexuality and disability
}

URL: www.sexualityanddisability.org

\section{Ana Lúcia Santos}

\section{(2) OpenEdition}

\section{Journals}

Edição electrónica

URL: http://journals.openedition.org/rccs/5511

DOI: $10.4000 /$ rccs.5511

ISSN: 2182-7435

\section{Editora}

Centro de Estudos Sociais da Universidade de Coimbra

Edição impressa

Data de publição: 1 dezembro 2013

Paginação: 141

ISSN: 0254-1106

Refêrencia eletrónica

Ana Lúcia Santos, "Título da página eletrónica: Sexuality and disability », Revista Crítica de Ciências Sociais [Online], 102 | 2013, posto online no dia 10 abril 2014, consultado o 22 setembro 2020. URL http://journals.openedition.org/rccs/5511 ; DOI : https://doi.org/10.4000/rccs.5511 


\section{Espaço Virtual}

\section{Título da página eletrónica: Sexuality and disability URL: www.sexualityanddisability.org}

Num contexto social em que a sexualidade é ainda tida como incompatível com a deficiência, principalmente quando se trata de mulheres deficientes, o sexuality and disability vem demonstrar que estas mulheres também são seres sexuais. O projeto resulta de uma iniciativa levada a cabo pela CREA - organização feminista de direitos humanos -, em conjunto com a Point of View - organização não governamental que recupera a voz das mulheres através dos média, da arte e da cultura -, ambas sediadas na Índia. A gestão da página é garantida por várias pessoas, desde mulheres com deficiência a ativistas pelos direitos das pessoas deficientes, profissionais de aconselhamento e ainda outras organizações dirigidas a pessoas com deficiência.

O principal objetivo deste projeto é desconstruir mitos e contribuir para o esclarecimento de dúvidas sobre sexualidade na deficiência. Dispõe de cinco separadores principais que tratam de questões relacionadas com o corpo, práticas sexuais, relações amorosas, maternidade e violência. Cada um destes separadores divide-se em subsecções que oferecem várias respostas a possíveis enunciados colocados por mulheres com deficiência. $\mathrm{O}$ website oferece uma série de hiperligações direcio- nadas para blogues, filmes, livros e outros sites temáticos no âmbito dos estudos sobre a deficiência, o feminismo, a sexualidade e o ativismo. Ao longo das suas secções é também possível encontrar hiperligações para trabalhos académicos, instituições de saúde e outras plataformas de informação. Não menos importantes são as secções voltadas para familiares, companheiros/as, entidades médicas e organizações associativas. Também aqui são oferecidas respostas a possíveis questões formuladas por parte de públicos que lidam diariamente com pessoas deficientes. A página inicial conta ainda com a coluna "A minha história" ("My story") que dá voz a histórias de vida narradas na primeira pessoa e a notícias relacionadas com a deficiência.

Devido à alargada rede de trabalho, este website oferece perspetivas inovadoras e multidirecionadas acerca da sexualidade de mulheres deficientes, pelo que resulta numa importante e vasta plataforma de acesso à informação, não só para as mulheres deficientes como também para um público mais alargado. Nesse sentido, sendo um site dirigido principalmente a pessoas com deficiência, é uma plataforma acessível cuja navegação se torna bastante intuitiva e clara.

\section{Título da página eletrónica: Associação Salvador URL: www.associacaosalvador.com}

A Associação Salvador é uma Instituição Particular de Solidariedade Social, sem fins lucrativos, que desde 2007 tem estatuto de utilidade pública. Fundada em 2003 por Salvador Almeida, a associação conta agora com uma equipa interdisciplinar e 
com a pareceria de empresas externas e o apoio de pessoas voluntárias. A associação tem desenvolvido importantes projetos nas áreas da integração social, acessibilidades e sensibilização, direcionadas a pessoas com mobilidade reduzida, especialmente deficientes motoras. No website é possível consultar vários projetos em curso: projetos que visam melhorar a qualidade de vida de pessoas com carências económicas através da prestação de apoio à integração profissional/formação, apoio à prática de desporto adaptado através, por exemplo, do fornecimento de materiais ou de transporte, e apoio ao desenvolvimento de um negócio próprio; projetos que visam o apoio ao emprego, desde workshops a ações de sensibilização em empresas, trabalhando em parceria com a Operação de Emprego para Pessoas com Deficiência e o Gabinete Pró-Emprego; projetos de desporto adaptado, desde dança a desportos aquáticos, desportos de pavilhão entre outros; eventos de convívio (gratuitos) de caráter lúdico, cultural e desportivo; projetos de acessibilidades, tais como o website e a aplicação para smartphones
"Portugal Acessível", que informa sobre os locais e itinerários acessíveis no país; ações de sensibilização de segurança rodoviária e palestras sobre inclusão realizadas em escolas. A Associação Salvador colabora ainda com projetos de investigação científica que tratem de questões sobre deficiência motora, prestando auxílio na divulgação do estudo e através da facilitação de amostra. A página possui ainda uma secção de perguntas frequentes (FAQs) sobre deficiência motora, acessibilidades, incentivos à contratação de pessoas com deficiência e outras informações úteis. De igual utilidade é a secção de notícias e eventos, não só relativos à Associação Salvador, como a outros. É possível ainda encontrar uma secção de testemunhos que dá voz a pessoas com deficiência através de entrevistas concedidas à associação.

Muito mais que informativa, esta é uma associação interventiva, que age diretamente sobre as pessoas e os espaços, e é esse caráter de serviço público que orienta a oferta disponível a partir do website.

Ana Lúcia Santos

\section{Título da página eletrónica: Global Uprisings URL: www.globaluprisings.org}

De protesto em protesto Brandon Jourdan e Marianne Maeckelbergh unem a investigação à linguagem documental numa representação fiel das primaveras que por todo o mundo se erguem. Mas a antropóloga cultural de Leiden e o jornalista independente que conta já com colaborações com o NY Times, CNN e Democracy Now!, rapidamente se juntaram a uns/ umas outros/as tantos e tantas, coletivos e independentes, dedicados a demonstrar as respostas à crise austeritária. Registando os mais diversos acontecimentos em sete países (Turquia, Grécia, Portugal, Egipto, Espanha, Estados Unidos e Reino Unido), Global Uprisings conta já com mais de meia centena de colaborações coletivas e individuais que reúnem testemunhos, imagens, sons de protesto, e promovem a sua difusão nos mais variados espaços da vida virtual.

Em Portugal, e juntamente com Luhuna Carvalho, antropólogo cineasta de Lisboa, registaram-se os momentos da resposta portuguesa ao apelo europeu de greve (14 de novembro de 2012), a sua preparação, 
a sua organização, os seus conflitos. Uma semana em dez minutos. Mas que bastam para demonstrar que não há bons ou maus alunos no plano austeritário, mas sim um crescente espírito de conflitualidade social e política que resulta da resposta à degradação económica dos povos a quem o plano é imposto.

$\mathrm{Na}$ Grécia dão voz aos imigrantes invisíveis na violência que os subjuga e que lhes é aplicada quer pela justiça racista das políticas gregas, quer pelas mãos dos ataques xenófobos da Aurora Dourada.

Registando o futuro incerto de milhões de pessoas, o espaço virtual é fácil de compreender e guia-nos para múltiplas realidades de resistência que se unem com importantes entrevistas com David Harvey e Paul Mattick Jr., promovendo assim uma simbiose entre o conhecimento antiausteritário que se produz na rua e o conhecimento antiausteritário que se produz nas mais altas camadas do setor intelectual.

A partir daqui, seguimos o caminho lógico da informação independente e dos movimentos que não esperam a edição do vídeo, e encontramos na sua página de Facebook (http://www.facebook.com/globaluprisings) a informação de que por vezes sentimos falta no site. Mas as duas são uma, pois hoje os espaços virtuais já não se desligam das comunidades virtuais, numa nova territorialidade e em novas formas de expressão de e-cidadania.

O método proposto por Global Uprisings, que une conhecimento com imagem, rua com academia, é pois sem dúvida, uma importante ferramenta para pensarmos o discurso antiausteritário, as formas de mobilização social, e o registo das suas memórias.

Irina Castro 